\title{
Impact of Range Goats on Infiltration Rates in Southwestern Utah
}

\author{
GERALD F. GIFFORD, FREDERICK D. PROVENZA, AND JOHN C. MALECHEK
}

\author{
Abstract
}

Three levels of goat browsing on a blackbrush site in southwestern Utah had no significant impact on infiltration rates. The probable reason for these results was the presence of a vesicular soil crust, which is unstable when wet and therefore masks any browsing impacts.

Watershed impacts of various classes of livestock are poorly defined. There is a complete void in the literature concerning the browsing impacts of goats. Grazing animals in general have an impact on local hydrology as reviews by Gifford and Hawkins (1978), Springer and Gifford (1980), and Blackburn et al. (1982) have shown. These reviews, however, contain no data specifically related to grazing or browsing schemes that utilized goats.

The objective of this study was to evaluate the impacts of 3 intensities of goat browsing on infiltration rates in a blackbrush (Coleogyne ramosissima) plant community in southwestcrn Utah.

\section{Site Description and Methods}

The study area is at an elevation of $1280 \mathrm{~m}$ and is located about $45 \mathrm{~km}$ northwest of St. George, Utah, near the village of Gunlock. Vegetation on the site consists of blackbrush (Coleogyne ramosissima) associated with juniper (Juniperus osteosperma) growing on a Pastura Loam with an A-C horizon sequence underlaid by a petrocalcic (caliche) horizon (Bowns 1973). The $A_{1}$ is a thin horizon of 0 to $7 \mathrm{~cm}$ in the open areas between plants and the soil texture is a sandy loam; the $C_{1}$ and $C_{2}$ horizons are loams and the petrocalcic horizon is located at depths ranging from 38 to $72 \mathrm{~cm}$ of soil profile.

The physical design of the experiment consisted of 2 blocks of 8 ha each. Within each block the control pasture was 1 ha, the heavily stocked pasture was 1 ha, the moderately stocked pasture was 2 ha, and the lightly stocked pasture was 4 ha. During 1977, 11 Angora goats were introduced into each pasture the first week in January and remained 59 days. During the winter of 1978, each pasture was grazed by 13 short-hair, Spanish-type goats for 72 days. Previous to this study the area had not been grazed by domestic livestock for several years.

\section{Infiltration Measurements}

All infiltration measurements were made with the Rocky Mountain infiltrometer (Dortignac 1951). Infiltration was calculated as the difference between applied rainfall (approximately $7.5 \mathrm{~cm} / \mathrm{hr}$ ) and runoff for specific time intervals (up to 28 minutes) from plots $0.23 \mathrm{~m}^{2}$ in size. Measurements were made during September of 1977 and 1978 on plots prewet to field capacity 24 hours prior to the rainfall simulation. Twelve replications ( 6 per pasture) were run within each grazing intensity during each of the 2 years. Cover (vegetal, litter, rock) characteristics were measured at 100 points

Authors are professor, assistant professor, and professor, respectively, Range Science Department, College of Natural Resources, Utah State University, Logan, 84322.

This work was supported by the Utah Agricultural Experiment Station (Proj. 749 and 755). Technical Paper No. 2631, Utah Agricultural Experiment Station, Logan, 84322.

Manuscript received October 30,1980 on each infiltrometer plot using an ocular device similar to that described by Ibrahim (1971).

In an effort to characterize the extent of trampling disturbance under the various grazing levels, 100, 200, and 400 random ocular estimates of percent disturbed soil surface were made in each of the 1,2 , and 4 ha pastures on 5 dates in 1977. A .31-m square frame, subdivided into smaller fractions, was used for making the ocular estimates. Disturbed soil was readily identified based on surface soil characteristics, sparse vegetal cover, and lack of rainfall during the measurement period. No attempt was made to determine how often a given area might have been trampled, but only if it had been disturbed.

\section{Results and Discussion}

Infiltration rates were not impacted by the various browsing intensities. Gifford and Hawkins (1978) reported that moderate and light grazing reduced infiltration rates after 30 minutes to about $3 / 4$ of the ungrazed conditions, while heavy grazing reduces infiltration rates to about $2 / 3$ of the moderate/light condition or $1 / 2$ of the ungrazed condition. The only significant differences among 1977 and 1978 treatments appeared in 1977 during early time intervals within a rainfall simulator run, the first year the site was grazed (Figs. 2 and 3). This lack of response is somewhat surprising because (as shown in Fig. 1) nearly $90 \%$ of the heavily browsed pastures had been trampled at least once, and even under light browsing over $50 \%$ of each pasture had been trampled during 1977. Dadkhah and Gifford (1980) have shown that trampling has a very significant impact on infiltration rates. Trampling was undoubtably increased in 1978 since more goats were browsing for a longer period of time, yet there were no significant differences among treatments in their effects on infiltration rates.

A probable cause for the lack of well defined grazing impacts is the vesicular soil horizon. Such horizons are marked by accumula-

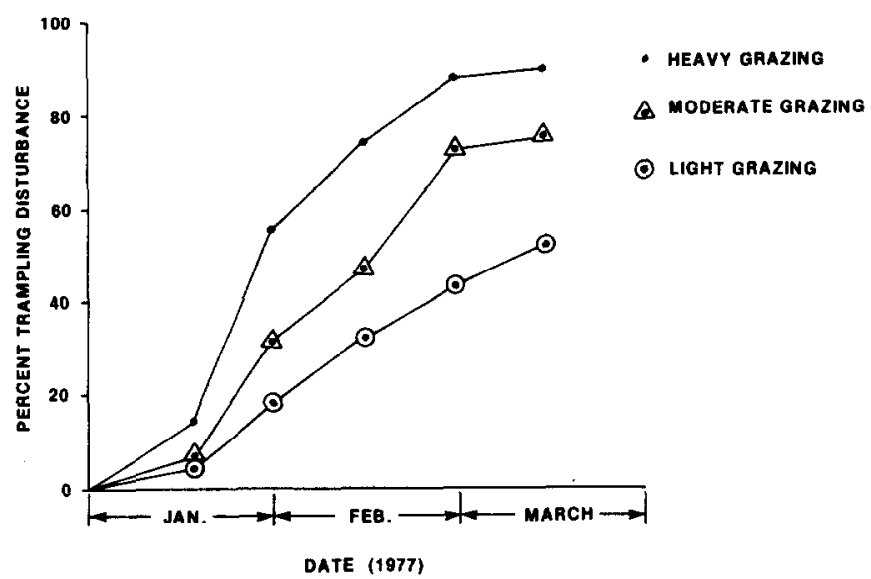

Fig. 1. Accumulated trampling disturbance for 3 browsing treatments during 1977. 


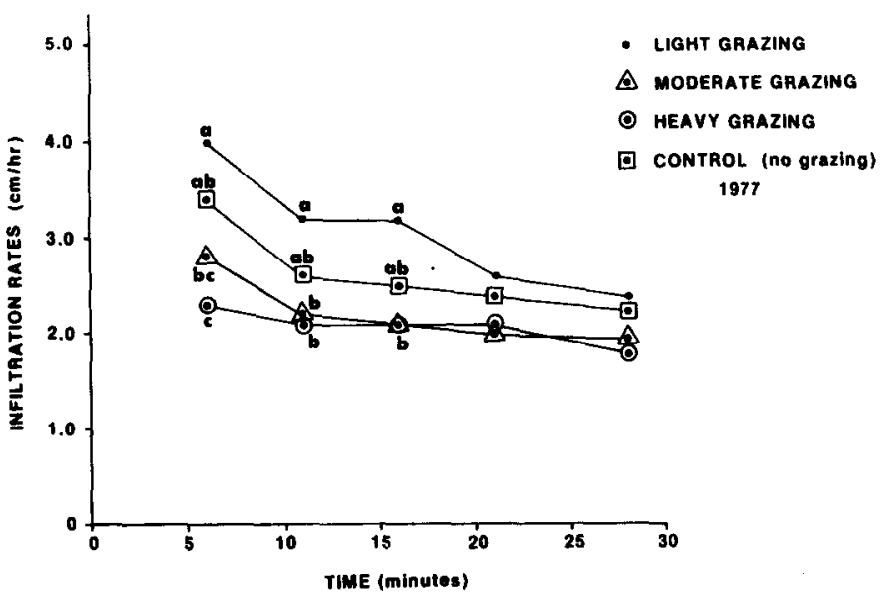

Fig. 2. Infiltration rates under various browsing treatments in 1977. Significant differences ( $\mathrm{p} \geq .05$ ) are noted for each time interval. There are no significant differences among treatments for the last 2 time intervals.

tion of spheroidal vesicles with relatively smooth walls which generally are isolated within the soil matrix. These horizons are thought to be formed through an interaction of entrapped air and wet soils, though the exact mechanism is not known (Hugie and Passey 1964, Springer 1958, Miller 1971).

Blackburn (1973) studied 28 plant communities and/or soils representing pinyon-juniper, northern desert shrub, and salt desert shrub vegetation zones in 5 watershed areas in central and eastern Nevada. He found that infiltration rates were negatively related to vesicular horizons and the strength of this relationship was dependent on vesicular horizon morphology.

Springer (1958) concluded that vesicular porosity was unstable, transitory, and quickly reformed in certain soils. The vesicular soils on this particular study site may have been sufficiently unstable to mask any impacts of specific grazing treatments. This hypothesis is supported by Eckert et al. (1979) who found that measured motorcycle and truck traffic had little effect on infiltration rates of soils with vesicular horizons but generally reduced the rates on soils without vesicular horizons. In addition, since cover characteristics measured in this study accounted for only $22 \%$ of the variation in infiltration rates associated with the different treatments, much of the variation has to be accounted for by such things as surface soil characteristics.

\section{Literature Cited}

Blackburn, W.H. 1973. Infiltration rate and sediment production of selected plant communities and soils in five rangelands in Nevada. Univ. Nevada Agr. Exp. Sta. Final Rep., Contract 14-11-0001-4632.

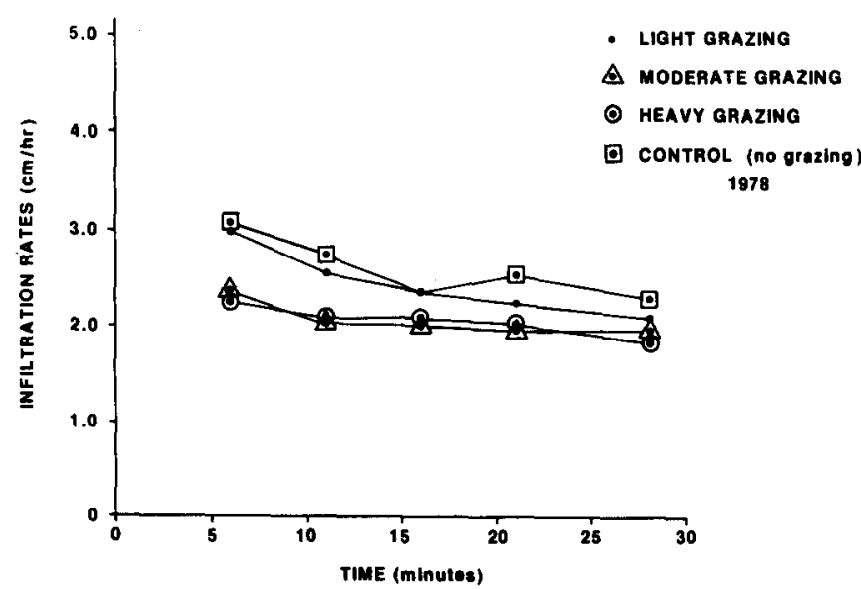

Fig. 3. Infiltration rates under various browsing treatments in 1978. There were no significant differences.

Blackburn, W.H., R.W. Knight, and M.K. Wood. 1982. Impacts of grazing on watersheds. Texas Agr. Exp. Sta. Bull. MP 1496 (College Station).

Bowns, J.E. 1973. An autecological study of blackbrush (Coleogyne ramosissima Torr.) in southwestern Utah. Ph.D. Diss., Utah State Univ., Logan.

Dadkhah, M., and G.F. Gifford. 1980 . Influence of vegetation, rock cover, and trampling on infiltration rates and sediment production. Water Resour, Bull, 16:979-986.

Dortignac, E.J. 1951. Design and operation of Rocky Mountain infiltrometer. USDA-FS, Rocky Mt. Forest and Range Exp. Sta., Pap. No.

Eckert, R.E., Jr., M.K. Wood, W.H. Blackburn, and F.F. Peterson. 1979. Impacts of off-road vehicles on infiltration and sediment production of two desert soils. J. Range Manage. 32:394-397.

Gifford, G.F., and R.H. Hawkins. 1978. Hydrologic impact of grazing on infiltration: a critical review. Water Resour. Res. 14:305-313.

Hugie, V.K., and H.B. Passey. 1964. Soil surface patterns of some semiarid soils in northern Utah, southern Idaho, and northeastern Nevada. Soil Sci. Soc. Amer. Proc. 28:786-792.

Ibrahim, K.M. 1971. Ocular point quadrat method. J. Range Manage. 24:312.

Miller, D.E. 1971. Formation of vesicular structure in soil. Soil Sci. Soc. Amer. Proc. 35:635-637.

Springer, M.E. 1958. Desert pavement and vesicular layer of some soils of the desert of Lahontan Basin, Nevada. Soil Sci. Soc. Amer. Proc. 22:6366.

Springer, E.P., and G.F. Gifford. 1980. Unconfined grazing and bacterial pollution-a review. In; A.S.C.E. Symp., Making Watershed Management Work, July 21-23, Boise: 578-587. 